\title{
Correction to: Transition Periods in the Diurnally-Varying Atmospheric Boundary Layer Over Land
}

\author{
Wayne M. Angevine $e^{1,2} \cdot$ John M. Edwards ${ }^{3} \cdot$ Marie Lothon $^{4} \cdot$ Margaret A. LeMone $^{5}$. \\ Simon R. Osborne ${ }^{6}$
}

Published online: 11 July 2020

(c) Springer Nature B.V. 2020

\section{Correction to: Boundary-Layer Meteorology https://doi.org/10.1007/s10546-020-00515}

In the original publication, Figures 1 and 2 are subject to Crown Copyright.

Publisher's Note Springer Nature remains neutral with regard to jurisdictional claims in published maps and institutional affiliations.

The original article can be found online at https://doi.org/10.1007/s10546-020-00515-y.

Wayne M. Angevine

Wayne.M.Angevine@noaa.gov

1 CIRES, University of Colorado, Boulder, USA

2 NOAA Chemical Sciences Laboratory, Boulder, CO, USA

3 Met Office, Exeter, UK

4 Laboratoire d'Aérologie, University of Toulouse, CNRS, UPS, Toulouse, France

5 National Center for Atmospheric Research, Boulder, CO, USA

6 Met Office, Cardington, UK 